\title{
Epidemiology of pleural mesothelioma in North-western Italy (Piedmont)
}

\author{
G. F. RUBINO ${ }^{1}$, G. SCANSETTI ${ }^{1}, A$. DONNA ${ }^{2}$, and G. PALESTRO ${ }^{3}$ \\ Institute of Occupational Medicine of the University of Turin', Institute of Oncology of the \\ Ospedale Maggiore di San Giovanni Battista e della Città di Torino ${ }^{2}$, and \\ Institute of Pathological Anatomy of the University of Turin ${ }^{3}$
}

\begin{abstract}
Rubino, G. F., Scansetti, G., Donna, A., and Palestro, G. (1972). Brit. J. industr. Med., 29, 436-442. Epidemiology of pleural mesothelioma in North-western Italy (Piedmont). Fifty-four cases of mesothelioma of the pleura admitted to the Chest Surgery Centre or to the Department of Medicine of the University of Turin from 1960 to 1970 are reported. Thoracotomy was performed in 22 . In the other 32 the diagnosis was based on the clinical, radiographic, and cytological findings and on the results of biopsy. In 50 cases (18 women and $32 \mathrm{men}$ ), the majority of whom had always or mostly lived in Piedmont, it was possible to ascertain the family history, previous residence, and occupation, mainly with the aid of information given by the patient's relatives. A similar investigation was made by the same interviewers into 50 other patients of the same sex and age admitted to the same institutions, using an identical technique. In the group with mesothelioma (only two of whom survived more than two years after the diagnosis had been made) occupational exposure to asbestos was demonstrated unequivocally in five men. Three other patients, including one woman, had lived with persons employed in the asbestos industry $(16 \%)$. Exposure for occupational reasons seemed very likely in another patient, who had been a fireman in the Turin Arsenal for 40 years. One man in the control group had worked for two years in a cement-asbestos manufacturing company $(2 \%)$.

A re-appraisal of the histological sections and examination of new preparations made in the 22 cases operated on was done in the Department of Pathological Anatomy of the University of Turin, also with the purpose of confirming the diagnosis. This re-appraisal revealed the presence of asbestos bodies in the mesothelioma in one case, a woman who had never been exposed to asbestos for occupational or domestic reasons but who had always lived in one of the two regions of the Province of Turin with the highest number of asbestos industries.
\end{abstract}

Primary tumours of the serous membranes form a rare group of conditions which can be diagnosed only with difficulty. In extensive necropsy series the incidence of pleural mesothelioma ranges from 0.4\% (Hochberg, 1951) to 7\% (König, 1960). In subjects exposed during their lifetime to the hazard of asbestos inhalation the incidence ranges from $0.7 \%$ (Knox, Holmes, Doll, and Hill, 1968) to $7 \cdot 6 \%$ (Anspach, 1968). In patients who have died from asbestosis the highest incidence is $11 \%$ reported by König (1960) from Hamburg.

After Wagner, Munday, and Harington (1962) reported a high incidence of mesothelioma in South Africa around crocidolite processing industries, many series of cases of mesothelioma in other parts of the world have been studied for the possibility of occupational, environmental or family exposure.

Table 1 shows the results of numerous investiga- 
TABLE 1

Pleural Mesothelioma and Exposure to Asbestos

\begin{tabular}{|c|c|c|c|c|c|c|c|c|c|c|c|}
\hline \multirow{2}{*}{ Author } & \multirow{2}{*}{ City } & \multirow{2}{*}{$\begin{array}{c}\text { No. of cases of pleural } \\
\text { mesothelioma (necropsy } \\
\text { or pneumonectomy) }\end{array}$} & \multicolumn{8}{|c|}{ Exposure to asbestos } & \multirow{2}{*}{ Comment } \\
\hline & & & \multicolumn{2}{|c|}{$\begin{array}{c}\text { Occupa- } \\
\text { tional } \\
\text { No. } \%\end{array}$} & \multicolumn{2}{|c|}{$\begin{array}{c}\text { Neigh- } \\
\text { bour } \\
\text { No. } \%\end{array}$} & \multicolumn{2}{|c|}{$\begin{array}{l}\text { Family } \\
\text { No. \% }\end{array}$} & \multicolumn{2}{|c|}{$\begin{array}{c}\text { Total } \\
\text { No. } \%\end{array}$} & \\
\hline $\begin{array}{l}\text { Hourihane (1964) } \\
\text { Anspach et al. (1965) } \\
\text { Newhouse and Thompson } \\
\quad(1965) \\
\text { Owen (1965) } \\
\text { Elmes and Wade (1965) } \\
\text { Webster (1965) } \\
\\
\text { Borow et al. (1967) } \\
\text { Lieben and Pistawka } \\
\quad \text { (1967) } \\
\text { Stumphius and Meyer } \\
\quad(1968) \\
\text { Jones (1968) } \\
\text { Ashcroft (1968) } \\
\text { Délage et al. (1968) } \\
\text { Chrétien et al. (1968) } \\
\text { Hägerstrand et al. (1968) } \\
\text { Milne (1969) } \\
\text { Rubino et al. } \\
\text { (unpublished) }\end{array}$ & $\begin{array}{l}\text { London } \\
\text { Dresden } \\
\text { London } \\
\text { Liverpool } \\
\text { Belfast } \\
\text { Johannesburg } \\
\text { Somerville } \\
\text { Harrisburg } \\
\text { Flushing } \\
\text { Nottingham } \\
\text { Newcastle } \\
\text { Clermont-Ferrand } \\
\text { Paris } \\
\text { Malmö } \\
\text { Melbourne }\end{array}$ & $\begin{array}{r}7 \\
17 \\
\\
76^{1} \\
17^{1} \\
42 \\
41 \\
\\
17^{1} \\
\\
42^{1} \\
\\
21 \\
6 \\
22 \\
5 \\
15 \\
27 \\
15\end{array}$ & $\begin{array}{rr}1 & 1 \\
2 & 1 \\
31 & 4 \\
12 & 7 \\
32 & 7 \\
32 & 7 \\
3 & 1 \\
10 & 2 \\
18 & 8 \\
2 & 3 \\
13 & 5 \\
2 & 7 \\
3 & 1 \\
12 & 8\end{array}$ & $\begin{array}{l}14 \\
12 \\
41 \\
70 \\
76 \\
78 \\
18 \\
24 \\
86 \\
33 \\
59 \\
13 \\
11 \\
80\end{array}$ & $\begin{array}{l}\overline{9} \\
11 \\
- \\
- \\
2 \\
8 \\
- \\
- \\
- \\
1 \\
1\end{array}$ & $\begin{array}{l}\overline{53} \\
14 \\
- \\
- \\
12 \\
19 \\
\overline{-} \\
\frac{27}{-} \\
-7\end{array}$ & $\begin{array}{l}- \\
- \\
9 \\
- \\
- \\
- \\
3 \\
- \\
- \\
- \\
- \\
-\end{array}$ & $\begin{array}{l}- \\
12 \\
- \\
- \\
- \\
7 \\
- \\
- \\
- \\
-\end{array}$ & $\begin{array}{r}21 \\
\\
18 \\
2 \\
50 \\
-2 \\
3 \\
13\end{array}$ & $\begin{array}{l}30 \\
50 \\
\\
86 \\
33 \\
91 \\
13 \\
11 \\
87\end{array}$ & $\begin{array}{l}\text { Crocidolite } \\
\text { only }\end{array}$ \\
\hline
\end{tabular}

'Including cases of peritoneal mesothelioma.

tions of this type and the incidence of histories of known exposure to asbestos.

It will be seen that only the smallest series (Délage et al., 1968) contains no case with a positive history of known exposure. In all the remaining series the incidence of occupational exposure to asbestos ranges from $11 \%$ (Hägerstrand, Meurman, and Ödlund, 1968) to $86 \%$ (Stumphius and Meyer, 1968).

This type of exposure is common mainly in the neighbourhood of crocidolite mines (Milne, 1969; Webster, 1965) and shipyards in Liverpool (Owen, 1965), Flushing (Stumphius and Meyer, 1968), and Belfast (Elmes and Wade, 1965).

The proportion of subjects considered to have been exposed to asbestos because they had resided for long periods within half a mile of asbestos industries is also noteworthy in the Dresden (Anspach, Roitzsch, and Clausnitzer, 1965) and Newcastle (Ashcroft, 1968) series. The largest series of cases reported (Newhouse and Thompson, 196576 cases) also included cases of peritoneal mesothelioma. Exposure by family contact (relatives with occupational exposure) was found in $12 \%$. When the various possible types of exposure are considered together, the incidence of a history of known exposure ranges from $11 \%$ to $91 \%$ (excluding the small series of Délage et al., 1968).

\section{Material and methods}

Our present investigation concerns 102 cases admitted to the Chest Surgery Centre or Department of Medicine of the University of Turin from 1960 to 1970 , in which the diagnosis was pleural mesothelioma.

Only three patients were investigated during their lifetime; in other cases the investigation was retrospective. In 76 cases the patient's previous occupation and place of residence could be ascertained, mainly from information given by relatives.

Thirty of these patients had been subjected to thoracotomy. The histological sections which had been prepared after the operation and others made specially for this investigation were re-examined. The histological diagnosis was confirmed in 18 cases. The clinical, radiological, cytological, and histological findings in the remaining 46 cases (who, like the foregoing group, had lived mainly or exclusively in Piedmont) were carefully re-appraised. In only 32 cases did the diagnosis seem reasonably certain.

Histological examination was done in four other cases subjected to thoracotomy. In these, as in the previously selected 18 cases, a search for asbestos bodies was made in the tumour tissue. Unfortunately, no relative of these last four patients could be found.

A similar investigation to that carried out in the 18 cases in which the diagnosis was confirmed histologically and in the 32 in which the diagnosis was confirmed on the grounds of other criteria was done in random patients of the same age and sex admitted to the same institutions. 


\section{Results}

\section{Cases subjected to exploratory thoracotomy}

The group of 18 patients subjected to exploratory thoracotomy in which the diagnosis was confirmed by examination of new histological sections as well as of the original preparations included nine men and nine women. Their mean age when the diagnosis was made was 55 (range 33 to 75 ) years. Five had lived mainly or only in the city of Turin, seven in the Province of Turin, and the remaining six in the other Piedmontese provinces (Table 2). Survival after the diagnosis was one year or less in 14, and a year and a half in 1 . The remaining 3 patients were still alive.

The occupations of the women in this group were as follows: housewife, 3; hat factory worker, 2; electric fitter, 1 ; lamp assembler, 1 . The remaining 2 patients were a tanner and a tool inspector. None had ever had any other job.

The men included 2 asbestos workers, 2 welders, 2 railwaymen, 1 carpenter, 1 steel worker, and a test driver. Five of this group had had other jobs for various periods of time ( 2 had been bricklayers, 2 shopkeepers, and 1 a furniture polisher). One man with no occupational exposure had lived for a long time with his wife who was employed in the asbestos industry.

Thus, $83 \%$ of the subjects in our series had had no occupational exposure, $11 \%$ had had occupational exposure, and $6 \%$ had had family exposure.
None of the 18 control subjects had ever been exposed to asbestos by occupation or family contact.

\section{Cases not subjected to thoracotomy}

The average age of this group was 57 (range 22 to 80 ) years; 23 were men and 9 women. Twelve had lived mainly or only in the city of Turin, 4 in the Province of Turin, and 16 in the other Piedmontese provinces. Twenty-nine had survived for one year or less after the diagnosis had been made, 1 had survived for a year and a half, 1 for two years and four months, and 1 for four years.

Four of the women had been seamstresses or shop assistants, 1 had been employed in a textile factory, 1 had been a housewife, 1 a clerk, 1 a countrywoman, and 1 had worked in a woollen mill.

The 23 men included 3 clerks, 3 car assemblers, 1 paper mill worker, 1 printer, 2 rubber industry workers, 1 confectioner, 1 smelter, 2 electricians, 1 tradesman, 1 hat factory worker, 2 asbestos carders, 1 mould maintenance technician in a friction material factory, 2 farmers, and 1 fireman in the Turin Arsenal.

Three cases $(9.4 \%)$ had certainly been exposed to asbestos, 1 (the fireman) had probably been exposed, and 2 had had family contact, having lived with relatives employed in the asbestos industry.

One of the 32 control subjects had worked for two years in a cement-asbestos factory.

TABLE 2

Cases Subjected to Thoracotomy

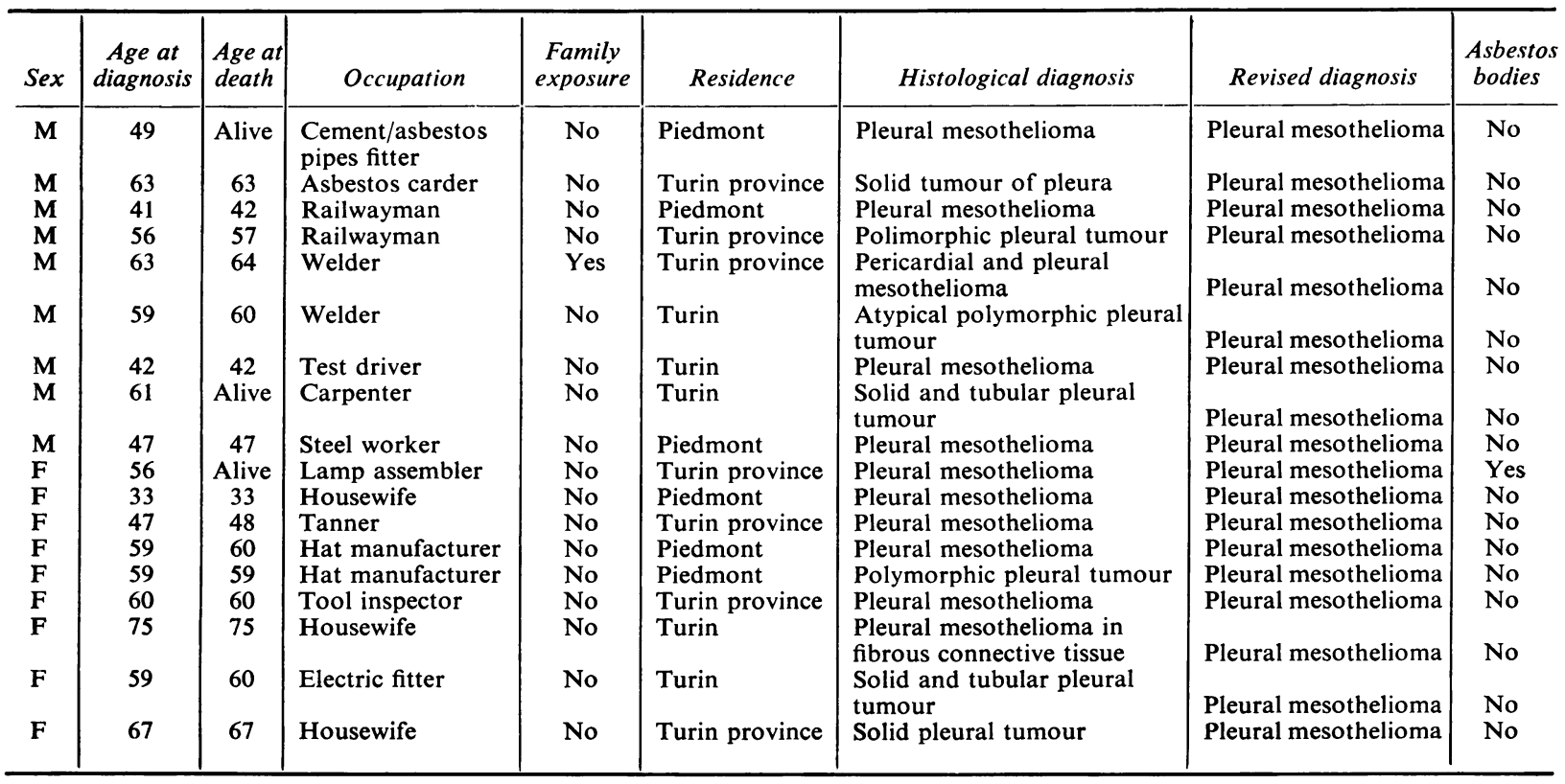


Examination of mesothelioma for asbestos bodies In the 22 cases in which the tissues excised during thoracotomy could be re-examined, a systematic search for asbestos bodies in the neoplastic tissue was made. Asbestos bodies were found in one of the 22 cases we were able to examine (Fig. 1). This patient was a woman with no occupational or family exposure to asbestos but who had always lived in one of the two areas of the Province of Turin where asbestos industries are most numerous.

\section{Distribution of pleural mesothelioma cases in Turin and Piedmont}

The findings concerning our cases in which no occupational or family exposure to asbestos could be established are shown in Figures 2 and 3. Eighteen cases who had lived mainly or only in the City of Turin are shown in Fig. 2, and 24 who had lived in the other parts of Piedmont are shown in Figure 3. The two maps also show the location of the main asbestos industries which have been active for at least 20 years in Piedmont.

The map of Turin shows that no case came from the town centre where no such industries have ever existed. Only in three cases in the northern part of the city was there a close proximity of the dwelling place to two brake and friction material factories of medium size.

The map of the entire Piedmontese region (Fig. 3) shows a considerable concentration of cases in the Province of Alessandria, with the exception of the Casale area where there is an important cement/ asbestos industry (two cases came from this city, an employee of this same factory and the sister of another employee who had lived together with her brother). Some cases came from the GrugliascoCollegno-Rivoli area to the west of Turin where some of the oldest and most important asbestos industries outside the city are located. The other two relatives of asbestos industry employees included in this series came from this area, as did the previously mentioned case with asbestos bodies in the neoplastic tissue (this is one of the three cases shown on the map in this area). A noteworthy fact is that no case of pleural mesothelioma came from the Province of Cuneo or Aosta and that only one each came from the Provinces of Vercelli and Novara, which are certainly no farther away from Turin than the Province of Alessandria, from which nine of our cases came (including the three hat factory workers).

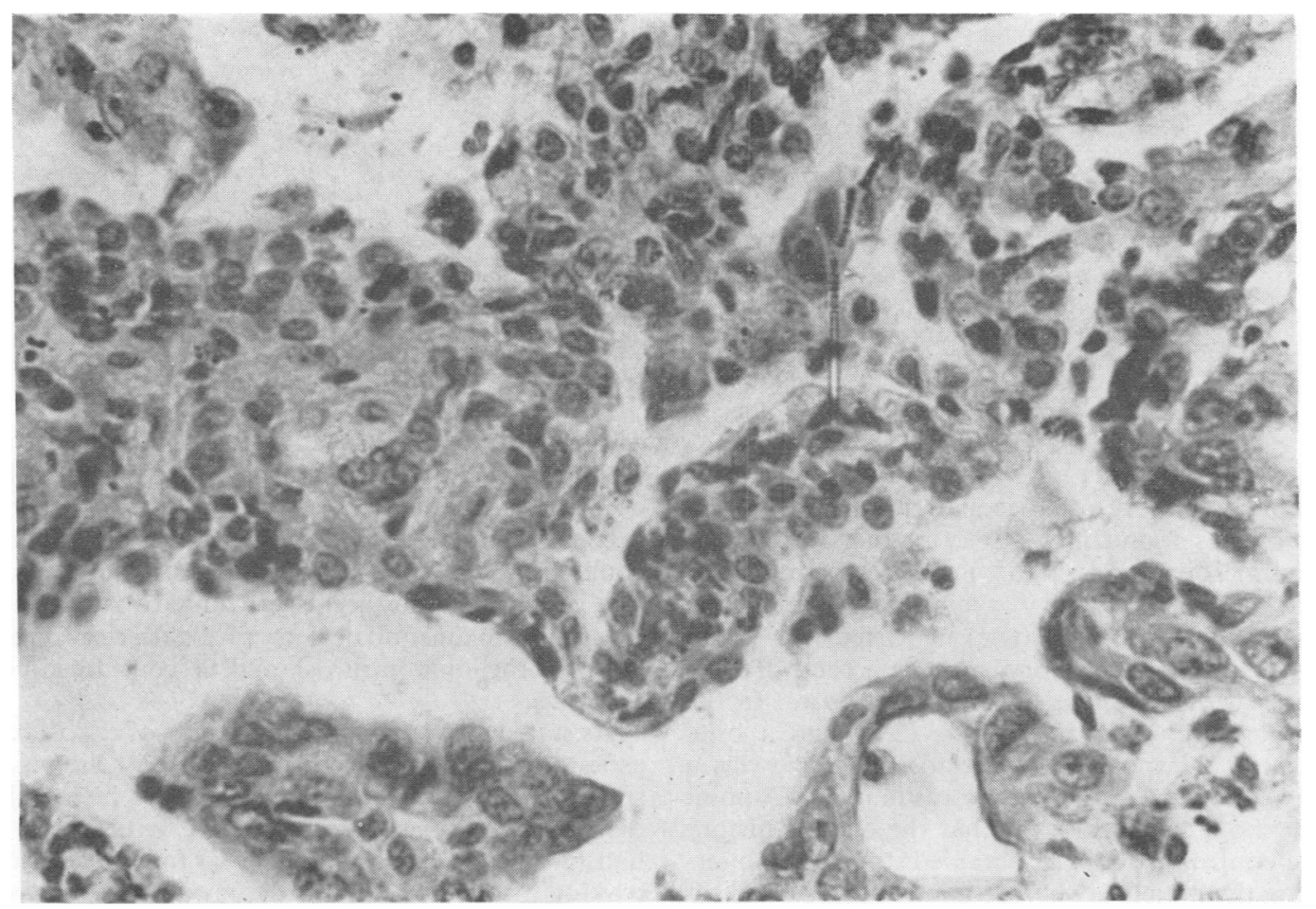

FIG. 1. A number of typical asbestos bodies can be seen at a greater magnification amid the neoplastic cells. Haematoxylin and eosin $\times 400$. 


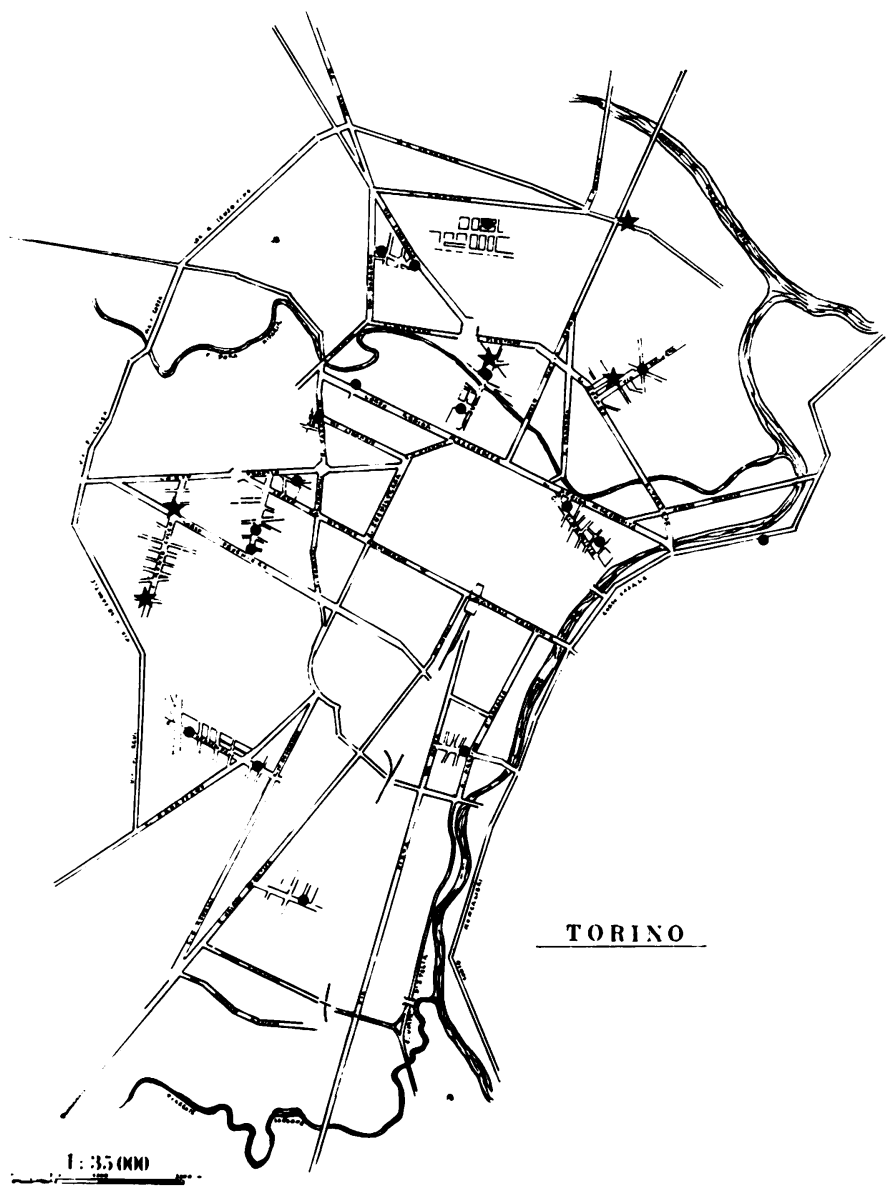

FIG. 2. Map of the City of Turin. $\star$ present or past asbestos processing factories (5) established for at least 20 years; residence of cases (18) of pleural mesothelioma in the Piedmontese capital.

\section{Discussion}

A definite history of occupational exposure to asbestos was found in $5(10 \%)$ of our 50 cases of pleural mesothelioma; 3 (6\%) other cases had lived for a long time with workers employed in the asbestos industry, and $3(6 \%)$ had lived near to an asbestos processing factory, making a total of $22 \%$ of cases with a definite history of exposure. In the control group, 1 of 50 subjects $(2 \%)$ had a brief occupational exposure to asbestos and none was a relative of a worker in the asbestos industry. A point which should be stressed is that the clinical history in the control group was obtained directly by interviewing the patients, whereas in most cases of mesothelioma the information was obtained at second hand by the same interviewers from the relatives who could give only information regarding certain major facts (exposure, main place of residence) but not many minor details regarding the patient's occupation, family life, and place of residence which could be ascertained exactly only in the controls. The conclusion thus seems warranted that the data regarding an unequivocal or probable exposure in the mesothelioma group should be considered conservative.

As stated previously, the incidences of exposure to asbestos in our two groups with mesothelioma are similar. Of the 18 cases in which the histological diagnosis could be re-appraised, 2 patients $(11 \%)$ had had occupational and $1(6 \%)$ family exposure, making a total of $17 \%$. In the group of 32 cases in which the diagnosis was made from the clinical, radiological, cytological, and biopsy findings the 


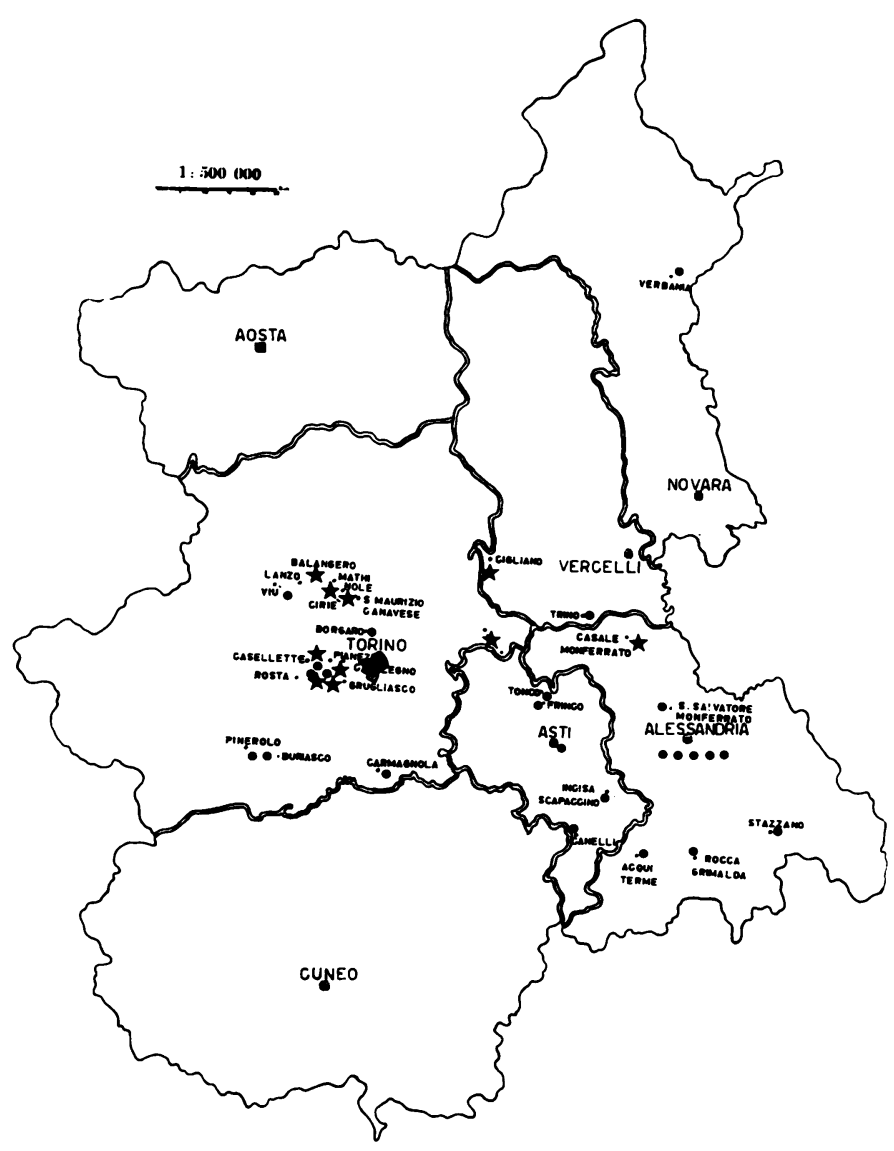

FIG. 3. Map of Piedmont. $\star$ main asbestos factories and mines (10), past or present, established for over 20 years; $O$ residence of cases (24) of pleural mesothelioma outside the capital of Piedmont. The double lines mark the boundaries between the seven Provinces of the Piedmontese region.

corresponding values were $9 \%$ and $6 \%$, making a total of $15 \%$. Of the three cases who had lived near established asbestos factories in the city of Turin, one belongs to the first group and two to the second. The two groups differ inasmuch as $50 \%$ of the cases in the operated group were women whereas only $28 \%$ of the second group were women.

An average of $10 \%$ of cases with a history of occupational exposure is close to the values reported in similar investigations by German (Anspach et al., 1965), French (Chrétien, Délobel, and Brouet, 1968), and Swedish (Hägerstrand et al., 1968) investigators (Table 1) but is much lower than that reported by English-speaking workers. This is probably due to the fact that crocidolite is little used in Piedmont where there is a considerable production of chrysotile. Studies on the possible relationships between exposure to asbestos and pleural mesothelioma have shown that such a relationship is much more common in cases of exposure to amphibolic asbestos (see South African and Australian reports).

Typical histological features were found in the cases in which the histological diagnosis was reconsidered, in 22 of which the diagnosis of mesothelioma was confirmed. All of these histological features were frequently found together in different parts of the same tumour.

Asbestos bodies were found within the mesothelioma in only one case. This apparent discrepancy between the high incidence of asbestos bodies in the 
sputum of subjects recently exposed to asbestos and, as reported by various workers (including Ghezzi, Molteni, and Puccetti (1967) and Donna (1968) in Italy), in crushed lung preparations made in consecutive routine necropsies in the general population, and the low incidence found in histological preparations in our cases of pleural mesothelioma is striking. However, histological preparations made with material obtained by biopsy usually include only the pleural lesion, i.e., a neoplastic tissue not directly involved in respiratory function. On the contrary, with the smear method the fluid expelled from a considerable portion of the lung (cut surface of an entire lobe) is examined.

\section{References}

Anspach, M. (1968). Todesursachen bei Beschäftigten in asbestverarbeitenden Betrieben Dresdens. Proc. 2nd int. Conf. Biological Effects of Asbestos. (In press.)

- - Roitzsch, E., and Clausnitzer, W. (1965). Ein Beitrag zur Aetiologie des diffusen malignen Pleura-Mesothelioms. Arch. Gewerbepath. Gewerbehyg., 21, 392-407.

Ashcroft, T. (1968). Proc. 2nd int. Conf. Biological Effects of Asbestos. (In press.)

Borow, M., Conston, A., Livornese, L. L., and Schalet, N. (1967). Mesothelioma and its association with asbestosis. J. Amer. med. Ass., 201, 587-591.

Chrétien, J., Délobel, J., and Brouet, G. (1968). Données étiologiques concernant 15 observations de mésothéliomes malins de la plèvre. Poumon, 24, 549-557.

Délage, J., Mercier, R., Molina, Cl., Cheminat, J. Cl., Fonck-Cussac, Y., and Lefebvre, G. (1968). Les tumeurs pleurales primitives. A propos de 5 observations. Poumon et Coeur, 24, 505-519.

Donna, A. (1968). Corpuscoli dell'asbestosi nel polmone umano reperiti nel comune materiale autoptico. Atti Convegno Studi sulla Patologia da Asbesto, Torino, 1968, pp. 49-61.
Elmes, P. C., and Wade, O. L. (1965). Relationship between exposure to asbestos and pleural malignancy in Belfast. Ann. N.Y. Acad. Sci., 132, 549-557.

Ghezzi, I., Molteni, G., and Puccetti, U. (1967). Asbestos bodies in the lungs of inhabitants of Milan. Med. $d$. Lavoro, 58, 223-227.

Hägerstrand, I., Meurman, L., and Ödlund, B. (1968). Asbestos bodies in the lungs and mesothelioma. (A retrospective examination of a 10-year-autopsy material). Acta path. microbiol. scand., 72, 177-191.

Hochberg, L. A. (1951). Endothelioma (mesothelioma) of the pleura. Amer. Rev. Tuberc., 63, 150-175.

Hourihane, D. O'B. (1964). The pathology of mesotheliomata and an analysis of their association with asbestos exposure. Thorax, 19, 268-278.

Jones, J. S. P. (1968). Proc. 2nd int. Conf. Biological Effects of Asbestos. (In press.)

Knox, J. F., Holmes, S., Doll, R., and Hill, I. D. (1968). Mortality from lung cancer and other causes among workers in an asbestos textile factory. Brit. J. industr. Med., 25, 293-303.

König, J. (1960). Über die Asbestose. Arch. Gewerbepath. Gewerbehyg., 18, 159-204.

Lieben, J., and Pistawka, H. (1967). Mesothelioma and asbestos exposure. Arch. environm. Hlth, 14, 559-563.

Milne, J. (1969). Fifteen cases of pleural mesothelioma associated with occupational exposure to asbestos in Victoria. Med. J. Aust., 2, 669-673.

Newhouse, M. L., and Thompson, H. (1965). Epidemiology of mesothelial tumours in the London area. Ann. N.Y. Acad. Sci., 132, 579-588.

Owen, W. G. (1965). Mesothelial tumours and exposure to asbestos dust. Ann. N.Y. Acad. Sci., 132, 674-679.

Stumphius, J., and Meyer, P. B. (1968). Asbestos bodies and mesothelioma. Ann. occup. Hyg., 11, 283-293.

Wagner, J. C., Munday, D. E., and Harington, J. S. (1962). Histochemical demonstration of hyaluronic acid in pleural mesotheliomas. J. Path. Bact., 84, 73-78.

Webster, I. (1965). Mesotheliomatous tumours in South Africa: pathology and experimental pathology. Ann. N.Y. Acad. Sci., 132, 623-646.

Received for publication August 31, 1971. 